\title{
Protecting the Forest or the People? Environmental Policies and Livelihoods in the Forest Margins of Southern Ghana
}

\author{
STEVE WIGGINS \\ Overseas Development Institute, London, UK

\begin{abstract}
KOFI MARFO and VINCENT ANCHIRINAH * Crops Research Institute, Council for Scientific and Industrial Research, Kumasi, Ghana
\end{abstract}

\begin{abstract}
Summary. - Although a wide range of policies to conserve the environment in the forest zones of southern Ghana exists on paper, in practice most are only applied in the commercially-valuable timber reserves. Environmental policies have little impact on those living in the forest margins since they are only sporadically applied, if at all. Indeed, even accepted community norms for resource use tend to be set aside when their application would interfere with key occupations. Livelihoods, however, depend heavily on natural resources, so conservation is necessary. The dilemma is to devise policies that are effective. Some decentralization of policy-making might improve matters, but care will be needed to avoid pitfalls.

(c) 2004 Elsevier Ltd. All rights reserved.
\end{abstract}

Key words - Ghana, decentralization, environmental policy, forestry, participation

\section{INTRODUCTION}

Do environmental policies harm the livelihoods of the poor living in and around environ- mentally sensitive areas? The dangers are that well-meaning measures to conserve the environment may have costs that fall on the poor who can least afford to bear them; and that those so

\footnotetext{
* At the Crops Research Institute (CRI), the authors were supported by the Director, Dr. J.A. Otoo, and assisted in this research by Mrs. Joyce Haleegoah, rural sociologist; Dr. J.N. Asafu-Agyei, Dr. H.K. Dapaah, and Dr. Stella Ennin, agronomists.

The authors thank the people of the four communities studied for their patience and participation in this study. We recognize the help given by government officers from the EPA and its regional offices in Ashanti and BrongAhafo, FC - in particular the staff of the CFMU and of the Forest Sector Development Project, MLF, MOFA, MEST, ME, the Regional Offices for Ashanti and Brong-Ahafo Regions, and the District Assemblies for Adansi East, Ejura-Sekyedumasi, Techiman and Wenchi Districts.

The project benefited from advice and support offered by Ms Helen Wedgwood of the Rural Livelihoods Office
}

of DFID in Accra, Dr. Christine Okali of the University of East Anglia, Dr. Elizabeth Harrison of the University of Sussex, and Dr. Margaret Quin of HTS Development Ltd. Two anonymous referees and Dr. David Brown of the Overseas Development Institute, London commented helpfully and pertinently on earlier drafts of this paper.

The Department for International Development (DFID), UK, funded this study as part of the Natural Resource Systems Program of the Renewable Natural Resources Research program as part of its support for policies, programs and projects that promote international development.

The interpretations and opinions do not, however, necessarily represent those of their sponsors and advisers. Final revision accepted: 21 May 2004. 
affected may thus ignore or deliberately contravene environmental policy measures to defend their livelihoods. Not only do issues of social fairness arise, but also the effectiveness of the policies may be affected.

Many of the policies designed specifically to protect natural resources - regulations on land and water use, restrictions on access, controls on extraction and harvesting of resources, controls and rules on disposal of wastes of effluents, etc.-will to some extent impose additional costs on some economic activities and social groups. How heavy these costs are depends in part on the importance of the resource in question to the livelihoods of affected persons. Hence particular concerns arise when livelihoods are closely tied to the use of natural resources. Examples include fisherfolk who use waters where quotas and bans have been imposed, such as those poor households harvesting shrimp seeds in coastal India, an activity banned in several States of India from the mid-1990s onwards (Salagrama, 2000), and herders where grazing lands have been excised for nature conservation (Sandford, 1983).

Tropical forests constitute a prime example of the challenges of sustainable development. They produce diverse goods and services (see Barbier, 1991), including those of tangible and immediate value such as timber, medicinal plants, fruit, etc.; those that arise indirectly through ecological systems, such as nutrient cycling, water conservation, and carbon storage; the option value of future uses of the forests; and the intangible existence values of forest biodiversity and landscape. For those who live and work in tropical forests, the returns to cutting forests for commercial timber, or to converting forest into cattle pasture or tree crop plantation, are often financially attractive, tangible, accrue to the landholder or occupier and generate returns within a few years of the initial investment. ${ }^{1}$ In contrast, when forest is degraded or cleared, the loss of environmental services may in large part fall on those current and future generations who neither live in forests nor own them. Without strong and effective countervailing regulation or incentives, those living and working in the forests here and now will thus tend to cut the forests back.

Apart from environmental concerns over the loss of tropical forest, there are social questions as well. Many of those living in and around the forests remain in poverty. In some cases, and to some degree, they do not have the capital or technical skills to take advantage of the oppor- tunities. But in other cases, they simply lack access rights to forest. For example, while some groups may have had longstanding use of the forest for hunting, gathering and subsistence farming, they have not had the rights to undertake logging or to convert forest permanently to agricultural use.

To make matters worse, policy for tropical forestry and for development in general has often encouraged large-scale conversion of forest. Public road building has removed the natural isolation of forests; ${ }^{2}$ cheap credits and tax concessions have funded logging, ranching and tree crop development (see Binswanger, 1991 for the case of Brazil); resettlement schemes have encouraged people to settle in the forest as farmers; and, some land titling regimes have made removal of primary forest a condition of getting formal title to the land (Angelsen \& Kaimowitz, 1999; Templeton \& Scherr, 1999). Indeed, it is difficult to have policies for economic growth in forested areas that do not, to some extent, encourage the removal of forest.

It is thus not surprising that tropical forests have been cleared and degraded at alarming rates in the last 50 years. During 1990-95, FAO reports that more than 65 million hectares of forest were lost in developing countries, out of 2,128 million hectares (Brown, 2001; Mather \& Chapman, 1995). Governments of developing countries have tried to limit the rate of forest loss by means such as establishing protected reserves where tree felling is banned or restricted, and otherwise regulating loggingmeasures enforced through state agencies.

All too often, these measures have been ineffective. Forests cover large areas that cannot be adequately policed. Some forest users have been able to ignore inconvenient rules: government staff meant to enforce them, bribed or impressed by the political connections of the violator, have ignored infractions. For example, the Forest Department in Madhya Pradesh, India, has tended to deny forest resources to locals, while turning a blind eye to the depredations of the powerful and its own staff (Sundar, 2001).

Consequently, forest policy has been reconsidered in many countries, resulting in attempts to involve locals in forest decision-making and implementation (Bass et al., 1997; Poffenburger, 1996). This, it is claimed, should allow decisions to reflect the diversity of local circumstances, give locals stronger rights to the resources and more say in decisions over their use, and so encourage them to conserve the forests. 
The rest of the article is set out as follows. The next section examines the case of environmental policy for the forests and forest margins of southern Ghana. The livelihoods of the people living on the edges of these forests are then described, and the reported interactions between environmental policy and those livelihoods investigated. Finally conclusions are drawn, with particular emphasis on the potentials and pitfalls of decentralized environmental policy-making.

\section{ENVIRONMENTAL POLICIES IN SOUTHERN GHANA}

Field work took place between April 2000 and October 2001. Environmental policies were recorded by examining official documents, and by interviewing officials in key ministries and agencies at central, regional and district levels. Leaders in the four villages surveyed were interviewed regarding community norms for resource management. One particular project, the 1997-2000 pilot program of Community Forest Committees, set up in 13 villages in three Districts, was evaluated briefly.

Although a wide range of policies may affect the rural environment - for example, a change in the exchange rate can lead to changes in land use-discussion here is limited to those policies explicitly and directly aimed at conserving the environment. Those policies affecting the forest margins of southern Ghana constitute a subset of policies both for environmental protection and conservation as well as for the management of natural resources in general. The environmental and natural resources that fall within the scope of this study include: forests, commons and waste lands, agricultural lands (fields, pastures and fallows), water coursesmainly rivers and streams, ${ }^{3}$ and wildlife living within these areas.

Responsibility for making environmental policy in Ghana is centralized, but otherwise spread quite widely. At central government level, the main ministries concerned are Food \& Agriculture (MoFA), Energy (ME), Environment, Science \& Technology (MEST), and Lands, Forests \& Mines (MLF), within which are found the Lands Commission and Forestry Commission (FC), the latter including the Wildlife Division (WD). MEST supervises the Environmental Protection Agency (EPA). This agency has overall responsibility for environmental regulation, advising other ministries on standards and guidelines, and ensuring implementation of environmental policies. Established in 1994, the EPA succeeded the Environmental Protection Council that had a purely advisory role.

In each of Ghana's 10 regions, there is a Regional Co-ordinating Council presided over by a Regional Minister. The Council is expected to coordinate the work of the regional offices of the central ministries and agencies. The EPA also has an office in each region.

Finally at District level there are District Assemblies (DA), partly elected (one third of members are appointed by central government, as is the chief executive-although that may change), that have the power to levy local taxes, pass by laws and implement projects. ${ }^{4}$ They are also expected to coordinate and supervise the work of central government agencies in their Districts. By law, each DA has a set of subcommittees, one of which deals with environmental health. In addition, in the early 1990s District Environment Management Committees (DEMC) were set up under the Ghana Environmental Resource Management Project (GERMP). The DEMC, however, is not a statutory body.

Ghanaian environmental policy is codified through: policy papers setting out government intentions; acts, laws and decrees that formally establish powers and responsibilities of different public agencies; legislative and executive instruments that describe the specific and legal extent of measures; by-laws setting out the former two elements at the district level; and, programs and projects with specific environmental aims financed by government usually with some donor assistance. The main policies applying in southern Ghana are set out in Table 1.

On paper, Ghana has an extensive portfolio of policy-certainly in terms of policy objectives and the broadest level of strategy - to conserve the environment in the forest belt of the south of the country. Coverage, however, is not necessarily complete or even. A notable omission from national regulations is charcoal-burning, for which measures can only be found at district level or in community norms. Moreover, in practice, the measures that are actually implemented depend in part on the degree to which policies are specifically and legally defined, and in part on the administrative capacity of agencies.

Taking the first point, definition matters, both practically and legally. Forest reserves, 
Table 1. Environmental policy in the forest belt of southern Ghana, 2001

\begin{tabular}{|c|c|}
\hline $\begin{array}{l}\text { Policy } \\
\text { affecting }\end{array}$ & Policy or program \\
\hline \multirow[t]{2}{*}{ Land use } & $\begin{array}{l}1990 \text { Control and Prevention of Bushfires Law } \\
\text { (PNDCL 192)-Shifted emphasis from } \\
\text { punishment of offenders to } \\
\text { regulation and prevention through education } \\
\text { and organization of early farming burning by } \\
\text { District Assemblies }\end{array}$ \\
\hline & $\begin{array}{l}1999 \text { National Land Policy-Intends to foster } \\
\text { equity and security of access to land, and its } \\
\text { sustainable management Declares } \\
\text { as protected areas: } \\
\text { — Forest reserves, strict game reserves, } \\
\text { national parks, wildlife sanctuaries, etc.; } \\
\text { - Slopes of } 30 \text { degrees or more, and; } \\
\text { - Areas within } 50 \text { - } 100 \text { m of the low } \\
\text { watermarks of permanent water sources }\end{array}$ \\
\hline
\end{tabular}

Water use 1996 Water Resources Commission Act (522)established the Commission, and confers extensive powers to regulate the abstraction of water and disposal of effluents into water courses

Pesticides 1996 Pesticides Control and Management Act (528)—All pesticides must be registered and classified.

All those dealing in pesticides must be licensed 2000-01 Crop Protection Policy, First Draft Sept. 2000; revised May 2001_notes the need to implement Act 528, proposes a greater role for the EPA in regulating pesticide use, calls for more promotion of integrated pest management

Forestry 1994 Forest and Wildlife Policy-Key document, signals commitment to forestry that serves more than just the timber industry, is sustainably managed, and which allows

other stakeholders a voice 1994 Trees \& Timber Amendment Act (493)Provides for the bi-annual renewal of property marks and the use of levies and other forest fees in the regulation of the timber trade: increases levies on the export of logs and the fees for renewal of property marks 1995 Interim Measures to Control Illegal Timber Harvesting Outside Forest ReservesIntroduces the farmer's right of veto and payment of compensation for crop damage More control on felling of trees off-reserve
Implementation

Most DAs have by-laws and programs that govern bush burning, including bans on burning by season or area, and codes of practice whereby any permitted burning has to be with the consent and supervision of local fire volunteers based in villages Protection of forest and game reserves implemented by the FC or WD, generally enforced with clear boundaries and guards to patrol and exclude unauthorized users Conservation of slopes and the margins of water-courses apparently not established in law Implementation left to DAs and Unit (i.e., village) Committees that have few if any resources to police the rules

WRC has few professional and technical staff, based only in Accra. Little done to arm the Commission with specific legal provisions, and even less to give it operational capacity in rural areas

MoFA

Little done to define specific measures and to implement legislation

MLF, through the FC Considerable resources of staff and equipment deployed through the forest zone to guard and supervise the use of the forest reserves Ensuring compliance with regulations off-reserve has had much less success. The restrictions on chainsaw use have proved difficult to implement

Some success in opening forestry decisions to local communities, but still far from engaging a meaningful level of participation 
Table 1-continued

\begin{tabular}{|c|c|c|}
\hline $\begin{array}{l}\text { Policy } \\
\text { affecting }\end{array}$ & Policy or program & Implementation \\
\hline & $\begin{array}{l}1997 \text { Timber Resources Management Act (547)- } \\
\text { Introduces Timber Utilization Contracts (TUC) for } \\
\text { any timber harvesting. Obliges timber } \\
\text { concession holders to negotiate with local } \\
\text { communities to produce Social Responsibility } \\
\text { Agreements (SRA) that stipulate social projects } \\
\text { and public infrastructure to be } \\
\text { provided to the community } \\
1998 \text { Timber Resources Management Regulations } \\
\text { (LI 1649) - Covers the procedures for the grant } \\
\text { of timber rights, sets timber stumpage fees and } \\
\text { contract area rent, and the registration and use of } \\
\text { chain saws - in effect setting severe restrictions } \\
\text { on the use of chain saws for converting timber }\end{array}$ & \\
\hline Wildlife & Reserves set aside and marked & WD \\
\hline Overall & $\begin{array}{l}\text { 1999-2009 National Resources Management } \\
\text { Program [NRMP] - a portfolio program embracing } \\
\text { specific projects, under five components: } \\
\text { - High Forest: includes policy and legislative reforms, } \\
\text { building capacity within the FC, } \\
\text { drawing up Forest Reserve Management Plans } \\
\text { for } 12 \text { Reserves and a National Forest Plan, } \\
\text { Off-Reserve forest management, Forest } \\
\text { Management Information System (mapping, inventories, } \\
\text { GIS), Forest Plantation Development Center to } \\
\text { encourage planting up forests, bush fire management in } \\
\text { transitional zone, and wood industry } \\
\text { development including certification } \\
\text {-Savannah: sets up the Savannah } \\
\text { Resource Management Center at Tamale } \\
\text {-Wildlife } \\
\text { - Biodiversity Conservation in High Forest Zone } \\
\text { - Coordination of Environmental Management } \\
\text { 1999 Environmental Assessment Regulation } \\
\text { (LI 1652)-Defines activities for which an } \\
\text { environmental permit is needed [does not cover } \\
\text { farming of areas under } 40 \text { ha], and the } \\
\text { procedures necessary [preliminary environmental report, } \\
\text { environment impact statement] to obtain } \\
\text { the annually-renewed permit }\end{array}$ & $\begin{array}{l}\text { MLF coordinates. Includes MoFA, } \\
\text { ME, MEST, MLGRD, Health } \\
\text { Coordinated via a Program } \\
\text { Coordination Unit (PCU) } \\
\text { Total budget US\$89M. Main } \\
\text { donors: IDA/GEF, DFID, } \\
\text { DANIDA, EU, WFP }\end{array}$ \\
\hline
\end{tabular}

Source: Official documents.

to take an example of a measure that is implemented, can be defended against improper use since they are defined and designated in law, are mapped and have physical boundary markers. In contrast, consider the National Land Policy's declared aim to protect the margins of watercourses to a depth of $100 \mathrm{~m}$. Implementation of this is patchy to nonexist- ent. In part this arises since the measure has only weak legal backing. No national legislation that establishes permitted and banned land uses on riversides exists, no clear definition of a "watercourse" appears in the policy-how much water is needed to constitute a "watercourse," the smallest trickle of a stream or just major rivers? - and no specific 
legal sanctions have been established for contravention.

On the second point, capacity to implement depends on either having the staff and equipment employed by public agencies to enforce policy, if necessary on an unwilling public; or else on the extent to which government policy is accepted as part of local norms and therefore voluntarily adopted by the public. In the two previous examples, forest reserves are patrolled by Forestry Commission staff based on site who have precise functions to police the reserves. Regulations can be, and are for the most part, enforced. The protection of riverside lands, on the other hand, is not specifically entrusted to any one body, other than as may be inferred from the general duties of, for example, members of Unit (effectively village) Committees and the staff of the District Assemblies. But there are no paid employees who have this specific remit. In this case, implementation depends almost entirely on the extent to which the measure falls within local norms and is voluntarily respected. As will be seen, in practice the norms are usually locally known but frequently set aside when economic imperatives apply.

In terms, then, of the policies that get implemented in the rural areas of the forest belt, the portfolio narrows and may, with only a little simplification, be reduced to two main clusters of policies. One concerns the forests, above all commercial forestry; the other includes local practices for land use.

\section{FORESTRY POLICY}

During the 20th century the population of southern Ghana increased by as much as 10 times. Although some of that increase has been absorbed by urbanization, rural populations have risen, accompanied by clearing of the forest to grow food crops and to plant commercial groves of cocoa and oil palm. Consequently the area's forests have increasingly been cleared, ${ }^{5}$ both to extract timber and to create farms. Little is left of the original primary moist tropical forests: in 1992 it was estimated that just $15,000 \mathrm{~km}^{2}$ of "intact closed forest," or $7 \%$ of the area of Ghana, remained (International Union for the Conservation of Nature, quoted in Kotey et al., 1998). Instead, much of the landscape is a mosaic of secondary forest, fallows, and clearings for food crops, cocoa and oil palm plantations.
Formal policy for the management of forests in southern Ghana dates back to the 19th century (see Kotey et al., 1998 for a history of forest policy), when colonial administrators recognized the need for policy to reconcile the competing demands of farmers and loggers for land and timber against the ecological benefits of forest cover - not least the value of trees for the micro-climate benefiting cocoa and other crops. Many of current forest reserves were established in the first half of the 20th century. From the early 1950 s through to the early 1990 s, forest policy became ever more concerned with regulating and facilitating the logging and wood industries, seen as key sources of foreign exchange and jobs for the newlyindependent country of Ghana. The interests of communities living in or close to the forests were marginalized. By the 1960s, small farmers found that trees on the land they farmed were not their property, whereas before they had been able to contract pit-sawyers to cut them (Amanor, 1999). ${ }^{6}$ Good quality timber trees standing on a field were thus a liability. The concession to fell them might be granted without the farmer's consent or knowledge, and when the contractor cut the tree, damage to crops was likely.

By the early 1990s it was clear that although the Forest Department (now the FC) was capable of controlling logging on concessions within reserves, the timber cut was excessive off reserve. Loggers cut trees beyond their permits, while farmers removed trees from their fields to avoid the liability of their being cut by contractors. A major re-think of policy resulted in the 1994 Forest \& Wildlife Policy. This envisages redistributing the balance of forest management rights and responsibilities from the timber industry toward farmers and landholders. As translated into subsequent forestry laws, it allows local stakeholders more say in decisions to cut trees, and directs that a portion of stumpage fees should be paid to local communities for development purposes.

Despite these changes, much remains to be done to transform forest policy to one that is not merely a tool of the commercial timber industry. The Forestry Commission's (2001a) review of the wood industry states bluntly that: "The choice of policies has failed to create the right incentives for improved efficiency and forest conservation at all levels of the Ghanaian forest sector." (p. viii) The report shows a timber industry that continues to cut way in excess of what is considered sustainable, ${ }^{7}$ with 
low milling efficiency, and in which loggers and processors take the lion's share of the resource rents from commercial forestry.

The aim of giving local communities more say in logging decisions and a larger share of revenues had hardly been achieved. An internal review of the main mechanism for this, the Social Responsibility Agreements (SRA) between loggers and local communities, reported that

\footnotetext{
"there is little evidence of community participation in the SRA processes... The fundamental problem is whether the landowners' representatives' interests do reflect those of the wider community beyond the institutional stakeholders. This set of SRAs does not appear to go much beyond the previous practice of concessionaires in their dealings with chiefs and the traditional authorities; they simply formalise current practice. Unsurprisingly, therefore, in this sample of SRAs there appears to be a skewed distribution of benefits and responsibilities between stakeholders." (Forestry Commission, 2001b, p. 5)
}

A recent official initiative to strengthen the ability of local communities to exercise their rights and negotiate with loggers, consists of a pilot program for Community Forestry Committees (CFC) set up in three Districts. It seems to have gained community acceptance, although the CFCs lack legal backing. As with so many local organizations, there are the seemingly inevitable problems with representation, accounting and honesty in some cases. The roles of the CFCs are not always clear. They have made most progress in promoting and implementing forest-based projects, but much less in presenting local opinion in negotiations and making policy, where the Committees have been sidelined in the negotiations of SRAs. This is worrying, since the idea of strengthening local governance of forestry was a prime motive to establish the CFCs.

Moreover, the setting of at least some forestry policy continues to be highly centralized with little or no consultation with the communities affected. For example, in 1998, a legislative instrument (1649) decreed a ban on the use of chainsaws to convert trees to lumber. Chainsaw operators had been extracting lumber from off-reserve fields and woodlands, both for local community use as well as for commercial sale. The ban aimed both to protect the offreserve trees as well as to try and improve the efficiency of conversion of felled wood into lumber which is notably low when using a chain saw. But there was apparently little recognition of, or perhaps sympathy for, the useful role that chainsaws played in meeting local needs for lumber, and of the demand in the domestic market for cheap, if somewhat roughly sawn, lumber. Implementation, however, has been partial at most. Although immediately after the decree, the supply of chainsawed lumber to the domestic market fell and prices shot up, within a year or two the prices fell and it seems that chainsawing was continuing at a barely diminished rate. The stringent restrictions on chainsaw use cannot be effectively policed. There are simply not enough staff to cover the large areas concerned, and in any case FC staff are not well enough paid to resist bribes or intimidation from clandestine loggers. Indeed, attempts to enforce this measure undermine the integrity of FC staff and respect for official policy in general.

In summary, then, forest policy is implemented unevenly. Measures concerning the forest reserves and commercial logging from concessions in the forest are largely respected. Off-reserve, moves to engage local communities have been only partly implemented and partly successful.

\section{LOCAL LAND USE NORMS}

The other set of environmental policy that gets implemented concerns local land use norms, affecting, among others, bush burning, the use of live wood for charcoal making, and cultivation close to river banks. Village leaders and elders are well aware of the desirability of controlling or limiting such activity. This concern is reflected in local norms that restrict or ban these practices. Porter and Young (1998) report similar norms for coastal Ghana:

\footnotetext{
"There is a widespread tradition of resource management through the application of taboos and regulation of various kinds. However, these cannot cope with the pressures now being imposed and in many cases are no longer respected" (p. 521). ${ }^{8}$
}

In some cases, local norms may also be codified in the by-laws passed by District Assemblies (DA). ${ }^{9}$ But there is not much evidence that the DAs have had much success in formulating or implementing environmental policy. For the four Districts covered in this study, the District Environmental Management Committees (DEMC) were moribund. Lacking statutory backing or any direct source of funding, unable even to pay the costs of their members to attend meetings, the DEMCs hardly ever 
met, let alone did anything - a result that echoes that of Porter and Young (1998) reviewing DEMCs in three coastal Districts.

Whatever the level of understanding of resource management and commitment to conservation that may exist at village level, actual implementation of local norms appears to be flexible. The codes are honored when possible and convenient. When economic imperatives conflict with these, they are usually set aside. Thus, vegetable growers who only have watering cans to irrigate their plots, cultivate right next to the riverbank to avoid the immense drudgery of hauling water by hand to plots that would, if they respected the exclusion zone, be $50 \mathrm{~m}$ to $100 \mathrm{~m}$ distant. This applies not just to plots that are off the beaten track and might escape detection: it can also be seen on riverbanks in clear sight of main roads. Charcoal burners claim they search first for dead wood, but when that is exhausted they cut live trees.

In sum, then, the environmental policy that gets implemented at field level is only a small part of what may be formally declared. ${ }^{10}$

\section{LIVELIHOODS AND ENVIRONMENTAL POLICIES IN FOUR VILLAGES}

To investigate the impact of environment policy on the livelihoods of those living in the forest belt, four villages were studied: Aboabo number 2, Adansi East District and Adiembra Nkwanta, Ejura-Sekyedumasi District, both in Ashanti Region; and Botenso, Wenchi District and Tanoso, Techiman District, both in Brong-Ahafo Region. These were purposively selected to reflect differing circumstances, mainly access to markets and the population mix of indigenous versus "settler" households, the latter being migrants usually from the northern regions of Ghana.

In three of the villages (Tanoso was not included in this phase), the main livelihoods carried out, awareness of environmental policy and appreciation of its impacts by the local population, were described through means of a participatory rural appraisal. Subsequently household composition and the main occupations of the members were recorded through a census of households in the four communities. This formed a sampling frame from which to select 55 households, each involved in one or more of four livelihoods that were seen in the initial field work to be especially susceptible to environmental policy: carpentry, chainsaw operations, charcoal production and vegetable growing. A formal questionnaire was administered to these households to seek details on these occupations and the extent to which they had changed in recent years.

The census of the four villages registered 533 households, ${ }^{11}$ with a median size of six persons, and a combined population of 3,434. The four communities differed in their ethnic composition. Aboabo and Tanoso were largely populated by indigenes, had slightly larger households and more female-headed households - one in three or more, compared to Botenso and Adiembra Nkwanta. The latter two were almost entirely settled by households from the north of Ghana, had slightly smaller households, very few female-headed households and had much higher ratios of adult men to adult women (125\% and $143 \%$ ), than the other villages. Incidence of adults recorded as nonresident varied, with an overall average of $20 \%$.

Livelihoods were centered on agriculture. The great majority of the households grew food crops, and for most of them, this was their main source of income. Vegetable production was the second most common occupation. Some households also had tree crops or livestock, but these were rarely the mainstays of their livelihoods. After farming, the principal occupations were charcoal making, artisan work (mostly carpentry), and small-scale trading. Other occupations and income sources were relatively rare.

Three points stand out. One is the high degree to which the households were self-employed, independent of labor markets. Few households worked for others, either on farms or on other jobs-less than $10 \%$ of the 55 surveyed households admitted to undertaking such work. ${ }^{12}$ Second, most households placed great importance on producing their own food. Third, most occupations were based on the use of local natural resources - above all, land, water, and trees.

Almost half the households in the census were engaged in one or more of the four occupations identified as vulnerable to environmental policies. Vegetable production was by far the most widespread of the occupations. Settlers, much in evidence in vegetable growing and charcoal-making, were more likely to undertake environmentally sensitive occupations than the native households. There was 
also some evidence that younger members of the communities were more likely to be engaged in these occupations.

For households engaged in one or more of these occupations, the median number of days worked was just 34, with more days worked in carpentry (49 days median) and chainsawing (96 days median) a year than in charcoal burning (19 days median) or vegetable growing (25 days median). ${ }^{13}$ Thus many of the jobs generated in these occupations were strictly parttime. Participation in these was highly uneven: just a few households were heavily engaged in one or other of the four occupations while the majority were only partially or even marginally engaged.

Median daily earnings in these jobs were US\$2.14 (average of just over US\$3.55). Variations were again great. Charcoal burning emerged as the best rewarded of the four occupations, chainsaw operations as the least well rewarded-although the data for chainsaws has to be treated with skepticism, given the reluctance of operators to admit to earnings from activities that were illegal or semi-legal at best.

The estimated earnings compare favorably to rural wage labor rates, the modal value of which was just US\$0.71 a day, with some reports of US\$1.43 a day applying in seasons when labor was scarce. That said, an estimate of returns to food crops at Adiembra Nkwanta, not a particularly productive farming site, gave a return of US\$3.50-US\$4.00 a day. This helps explain the priority given to growing food crops.

During the initial reconnaissance in three communities, groups were asked about their awareness and perceptions of environmental regulations. Table 2 summarizes their responses.

In all three settlements, people were well aware of the existence of policies and regulations, with the exception of those applying to the safe use of pesticides.

Perceptions and enforcement varied. The ban on chainsaw use was typically seen as bad since it harmed local livelihoods. In these cases, enforcement was left to the Forestry Commission that found it difficult to enforce and complained that punishments were not sufficient to deter chainsaw operators. In Botenso, however, the ban was welcomed since the settlers who made up the bulk of the population had no control over the trees on their land and feared crop damage from illegal chainsawing.
Bush fire and riverain planting regulations were widely seen as good and were enforced, partly through educational campaigns by the Fire Service and District Assemblies, but mainly through village authorities such as Unit Committees and elders. In Adiembra Nkwanta, fires were set by hunters from outside the community over whom the local population had no control. The locals complained that the hunters had permits issued by the District Assembly. The inability to prevent group hunting was probably linked to the poverty and low status of the settlers of Adiembra, compared to wealthier indigenes of neighboring communities with better political connections.

Only in Botenso was there any recognition of pesticide regulations. They were also accepted, with locals claiming that they did follow codes in response to extension messages. Otherwise, these rules were unknown and unenforced.

Bans on group hunting were seen as good. Since no locals went hunting in groups, there was nothing to enforce. The exception to this was the problem with outsiders hunting in groups in Adeimbra Nkwanta, as noted.

Rules to confine livestock were seen as unimportant in Aboabo, reflecting the lack of livestock in that community, as bad in Adiembra and as good in Botenso. Perceptions seem to correlate with the presence or absence of significant numbers of livestock. Enforcement was mainly local and depended on local perceptions.

Finally, that charcoal should be made from dead wood was well known, but for lack of dead wood, most charcoal was made from live wood. The rule was not enforced.

Overall, three points stand out. First, in most cases and most communities, people were aware of the existence of controls on the use of natural resources. Second, perceptions varied largely according to the effect of the policies on livelihoods - see below. Where the rules were likely to protect crops, people were in favor. When they prevented or made more difficult an important activity, the rules were opposed. Third, enforcement was only effective when implemented through village structures with community backing. Otherwise, the efforts of central government agencies, and even those of the District Assemblies, were widely ignored when they ran counter to village interests.

Looking at the impact of environmental policy on these and other activities, there were mixed reports as shown in Table 3. 
Table 2. Awareness, perceptions and enforcement of environmental policies and regulations

\begin{tabular}{lcccc}
\hline Policy and & Awareness & $\begin{array}{c}\text { Perception } \\
\text { of policy by } \\
\text { majority }\end{array}$ & District & Enforcement \\
\cline { 3 - 5 }
\end{tabular}

Ban on timber felling (with chain saw) without permit

\begin{tabular}{|c|c|c|c|c|}
\hline Aboabo No. 2 & High & $\mathrm{Bad}$ & $\begin{array}{l}\text { By Forestry Service; } \\
\text { personnel find it difficult. } \\
\text { Punishment for offenders } \\
\text { not enough to deter others }\end{array}$ & $\begin{array}{l}\text { Not interested in enforcement; } \\
\text { farmers not consulted on timber } \\
\text { tree management }\end{array}$ \\
\hline Adiembra Nkwanta & High & Bad & $\begin{array}{l}\text { By Forestry Service; } \\
\text { personnel find it difficult. } \\
\text { Punishment for } \\
\text { offenders not } \\
\text { enough to deter others }\end{array}$ & $\begin{array}{l}\text { Not interested in enforcement. } \\
\text { Ban seen as applying to cutting } \\
\text { any trees thus threatening } \\
\text { charcoal-burning, a key } \\
\text { local livelihood }\end{array}$ \\
\hline Botenso & High & Good & By Forestry Service & $\begin{array}{l}\text { Settlers who constitute the bulk } \\
\text { of the population had no control } \\
\text { over timber species }\end{array}$ \\
\hline
\end{tabular}

Bush fire control

$\begin{array}{lll}\text { Aboabo No. } 2 & \text { High } & \text { Good } \\ \text { Adiembra Nkwanta } & \text { High } & \text { Good }\end{array}$

Botenso High Good

Hunting (no group hunting)

Aboabo No. 2 High

Good

By Fire Service through educational programs

$\begin{array}{lll}\text { Adiembra Nkwanta } & \text { High } & \text { Good } \\ \text { Botenso } & \text { High } & \text { Good }\end{array}$
By Fire Service through educational programs

Riverain protection

Aboabo No. 2

$$
\text { High }
$$

Good

Adiembra Nkwanta

High

Good

Botenso

High

Good

By Fire Service through educational programs

Enforced; education as well as sanctions for offenders Enforced within community, but outsiders over whom there is no control cause bush fires through group hunting Enforced within community by Unit Committee

No group hunting District Assembly Education by District Assembly Education by District Assembly

Not able to enforce as hunters do not reside in the village No group hunting

Enforced; traditional customs pre-dated policy Enforced; traditional customs pre-dated policy Enforced; traditional customs pre-dated policy

Safe use of pesticides Aboabo No. 2 Low None

Not enforced; MOFA responsible through extension

Adiembra Nkwanta Low None Not enforced; MOFA responsible through extension

Botenso Fair Good

Not enforced; MOFA responsible through extension

Confinement of livestock Aboabo No. 2
No strong views By environmental health (livestock not important) personnel of District Assembly
Unit Committee expected to enforce 
Table 2-continued

\begin{tabular}{|c|c|c|c|c|}
\hline \multirow{2}{*}{$\begin{array}{l}\text { Policy and } \\
\text { community }\end{array}$} & \multirow[t]{2}{*}{ Awareness } & \multirow{2}{*}{$\begin{array}{l}\text { Perception } \\
\text { of policy by } \\
\text { majority }\end{array}$} & \multicolumn{2}{|c|}{ Enforcement } \\
\hline & & & District & Community \\
\hline Adiembra Nkwanta & High & $\mathrm{Bad}$ & $\begin{array}{l}\text { By environmental health } \\
\text { personnel of District Assembly }\end{array}$ & $\begin{array}{l}\text { Unit Committee expected to } \\
\text { enforce but not enforced }\end{array}$ \\
\hline Botenso & High & Good & $\begin{array}{l}\text { By environmental health } \\
\text { personnel of District } \\
\text { Assembly }\end{array}$ & $\begin{array}{l}\text { Unit Committee expected to } \\
\text { enforce but not regarded } \\
\text { as a threat }\end{array}$ \\
\hline \multicolumn{5}{|c|}{ Dead wood for charcoal } \\
\hline Aboabo No. 2 & High & Not effective: & No by-law to back policy & No enforcement \\
\hline Adiembra Nkwanta & High & $\begin{array}{l}\text { dead wood } \\
\text { scarce }\end{array}$ & $\begin{array}{l}\text { Draft by-law; not yet } \\
\text { legally operational }\end{array}$ & No enforcement \\
\hline Botenso & High & & $\begin{array}{l}\text { Draft by-law; not yet } \\
\text { legally operational } \\
\text { Promotion of wood lots as } \\
\text { alternative source of wood }\end{array}$ & No enforcement \\
\hline
\end{tabular}

Source: Reconnaissance surveys.

Although the impacts reported were diverse, most policies had not had a substantial impact, with the exception of the 1998 ban on using chainsaws to cut commercial lumber. But even this measure seems to have had only a shortlived impact in reducing jobs in chainsawing and portering, and in pushing up the price of lumber and timber in the domestic market, to the detriment of carpenters and their customers. Subsequently, the evidence suggests that chainsawing continues where it is an essential component of rural livelihoods - as in the cases of cutting trees for carpentry lumber in Aboabo or in sawing timber to be made into charcoal in Adiembra Nkwanta. This pattern of continuity in defiance of policy seems reflected in the wider economy: supplies of chainsaw lumber carry on flowing to rural economies and the national market at volumes similar to those preceding the ban.

Hence the main finding from the village studies is that environmental policy has had little impact on livelihoods in the forest margin communities, largely since so little policy is effectively and consistently implemented or enforced.

\section{DISCUSSION OF FINDINGS AND IMPLICATIONS}

Despite all manner of good intentions and much effort to formulate environmental policy for the forest belt of southern Ghana, little of this policy translates into effective action in the field. Indeed, implemented policy comes down largely to that affecting the control and supervision of commercial timber felling - and even then mainly that taking place on the forest reserves; and the degree to which local communities are prepared to uphold longstanding norms about bush burning, using only dead wood to make charcoal, and not cultivating on the margins of rivers and streams, among others. But local norms, it seems, are honored only when they do not prevent activity that provides local jobs and incomes. When they do, they are set aside, albeit sometimes with regret by those involved.

Given how little of policy is actually put into effect, it is not surprising that this study was unable to detect any substantial (direct) impacts on the livelihoods of people living in the forest margins.

At first sight, then, we may conclude that we need not worry about policy that is not implemented. But that would lose sight of matters both of principle and practice.

In principle, the failure to implement environmental policy is perturbing. No one doubts that in the forest belt of southern Ghana unprecedented changes in land use over the last 100 or so years have taken place. Some of these, particularly the cutting back of the high forest, reduction of habitat for wild fauna and flora with probable loss of biodiversity, the potential for increased erosion from cleared plots, possible over-abstraction of some water resources 
Table 3. Impacts on livelihoods of environmental policies

\begin{tabular}{|c|c|}
\hline Affected occupations & $\begin{array}{l}\text { Policy and impact }[\text { Village in question in parentheses: } \\
\qquad \begin{array}{l}\mathrm{AA}=\text { Aboabo, } \mathrm{AN}=\text { Adiembra Nkwanta, } \\
\text { BO = Botenso, } \mathrm{TO}=\text { Tanoso }]\end{array}\end{array}$ \\
\hline \multicolumn{2}{|c|}{ Ban on chainsawing for timber } \\
\hline Chainsaw operators & $\begin{array}{l}\text { Some lost income as services no longer required; some operators moved into } \\
\text { farming while others have emigrated. Loss of income reduces capital for farming. } \\
\text { But chainsaws still much used for cutting timber and lumber [AA] } \\
\text { Chainsawing of timber and lumber apparently ceased in TO }\end{array}$ \\
\hline Wood carriers & Lost wages from transporting sawn timber from fields to assembly points [AA] \\
\hline Sawn wood dealers & Lost income from reduced sales $[\mathrm{AA}]$ \\
\hline Carpenters & $\begin{array}{l}\text { Lack of sawn wood drives up price for furniture, doors, window frames - and hence: } \\
\text { Less demand for construction works (new buildings), less demand for furniture [AA] } \\
\text { In TO, carpenters have moved from using bush-cut lumber to sawmill wood } \\
\text { (often rejects) }\end{array}$ \\
\hline Masons & $\begin{array}{l}\text { Less demand for services as mud houses (the most common) unable to } \\
\text { stand rains for long without roofing; less people building because of } \\
\text { higher prices for roofing timber [AA] }\end{array}$ \\
\hline Charcoal makers & $\begin{array}{l}\text { Production cut drastically, incomes down, as left-overs from felled trees no longer } \\
\text { available for charcoal production [AA] } \\
\text { Little impact: chainsaw operators from Ejura visit to fell trees [AN] } \\
\text { Little impact: only } 2 \text { men so employed [BO] } \\
\text { Overall, reports that wood is increasingly difficult to find and that live wood is used. }\end{array}$ \\
\hline $\begin{array}{l}\text { Consumers of timber } \\
\text { (building, furniture) }\end{array}$ & Higher prices for products [AA] \\
\hline \multicolumn{2}{|l|}{ Bush fire controls } \\
\hline Farmers & $\begin{array}{l}\text { Loss of crops prevented }[\mathrm{AA}],[\mathrm{AN}],[\mathrm{BO}] \\
\text { Improved soil fertility through organic matter conservation }[\mathrm{AA}],[\mathrm{AN}],[\mathrm{BO}]\end{array}$ \\
\hline Hunters & $\begin{array}{l}\text { Less game caught since setting of fire makes catches easier (little adverse impact- } \\
\text { few hunters and bullets also very expensive) [AA] }\end{array}$ \\
\hline \multicolumn{2}{|l|}{ Riverain protection } \\
\hline Farmers & $\begin{array}{l}\text { Farmers with fields by rivers reported little impact }[\mathrm{AA}] \\
\text { Little impact: a traditional practice }[\mathrm{AN}],[\mathrm{BO}]\end{array}$ \\
\hline \multicolumn{2}{|l|}{ Safe use of pesticides } \\
\hline Vegetable producers & $\begin{array}{l}\text { Little impact-few people, no knowledge [AA] } \\
\text { Little impact: follow old practices, no education }[\mathrm{AN}],[\mathrm{BO}],[\mathrm{TO}]\end{array}$ \\
\hline \multicolumn{2}{|c|}{ Confinement of livestock } \\
\hline Livestock keepers & $\begin{array}{l}\text { Little impact-livestock not important }[\mathrm{AA}],[\mathrm{BO}] \\
\text { Little impact: livestock not contained }[\mathrm{AN}]\end{array}$ \\
\hline
\end{tabular}

Source: Initial reconnaissance, survey data.

and pollution of others, etc.-are legitimate causes for concern.

That said, relatively little is known with any degree of scientific certainty or precision about such environmental changes. Data series that can be compared through time exist for areas under forest, off-take of timber, climate, and perhaps also on the prevalence of some wildlife species - but on little else. Given the complexity of natural systems, for several important processes we have only an outline of what may be happening.
Questions about precise physical changes is echoed by similar uncertainty over the impacts of such change on livelihoods, the potential responses of those affected, and even about how they perceive such change. ${ }^{14}$

In practice, furthermore, the current situation of having many policies on the books that are simply not implemented presents a threat and source of uncertainty to those making their living in the forest margins. Dormant but legal policy allows episodic "campaigns" of enforcement, by government officers, police and secu- 
rity forces, to be mounted. Such campaigns are necessarily short-lived since staff have other matters to attend, so they are unlikely to be effective in the longer term. But for the short periods they apply, they can disrupt the local economy, constitute a sudden high tax on activity, and be socially inequitable. The very possibility of such campaigns introduces uncertainty to activities widely seen as legitimate, even if they flout some regulation or other. Campaigns have the added disadvantages of making government appear oppressive - and consequently a power whose intentions can legitimately be ignored or opposed; as well as increasing the possibility of bribery or coercion of those trying to enforce policy, with consequent undermining of civic values.

These objections might be taken as grounds for proceeding with caution or just doing nothing. But to do so would be to ignore that pressures on the environment of southern Ghana are unlikely to diminish in the near future. Population is growing, urbanization is increasing. Both popular aspirations and official policy favor more economic growth in a region where much of economic activity is based on the use of natural resources. Even allowing for some changes in technology and the structure of economic activity that may ameliorate the pressure on natural resources, human impact on the environment will almost certainly increase in the short and medium terms. To reconcile such impacts with the conservation of environmental benefits for current and future generations, environmental policy is needed.

Policy formulation and implementation, for the environment as for other parts of public life, may be something that government and society need to practice, to develop capacity. Put simply, if we cannot make some progress toward resolving today's environmental problems, what chance will there be of tackling the (probably larger) challenges of the future?

Yet quite what might constitute effective environmental policy in southern Ghana, both in principle when little is known about both physical processes and their economic and social consequences, and in practice when implementation can be difficult, is far from clear. What is clear is that, given the degree to which rural livelihoods in the forest margins depend so very heavily on the use of local natural resources, inappropriate or ill-considered environmental policy has the potential to reduce jobs and incomes of people, most of whom are already poor by any definition.
How, then, to move forward, when the stakes are high in terms of both livelihoods and the environment, and when physical processes and human consequences are uncertain?

Currently in Ghana most environmental policy is made centrally. Doing so has the virtue of being able to take into consideration the widest interests of society, including those of current and future generations. Centralization simplifies co-ordination and consistency of policy. But making policy requires reasonably reliable information about environmental processes and about the livelihoods of the people affected. When such information is scarce, the ability of the center to make broadly correct decisions is limited. Even then, it is not clear that attempts to enforce centrally-decided measures, however wise, that do not have local assent will ever be fully effective, without incurring unduly high costs in staff and operating budgets.

\section{DECENTRALIZATION AS A WAY FORWARD?}

Such circumstances suggest decentralizing environmental policy-making and implementation. This could make fuller use of local knowledge and insights and allow policy to be more tailored to local needs. Impacts on the livelihoods of those living in the rural areas are less likely to be ignored or discounted. It may also avoid making big mistakes that can arise when central policy is ill-informed by local realities.

On other hand, decentralization can lead to incoherent and uncoordinated policy made without either accurate information or professional analysis. It may also lead to policy that represents the interests of local elites alone, or which rides roughshod over the interests of minorities. It may produce populist policy that takes little account of wider implications.

What is known about decentralized environmental policy-making? For decentralization as a development measure in general, the literature (see, for example the reviews by Bardhan, 1996; Manor, 1999) suggest qualified support. Qualified, since much depends on context and circumstances.

Experiences to date with decentralized control of natural resources and environmental policy have been mixed. Larson (2002) reports that decentralization in Nicaragua has led to led to municipalities taking more control over forests, issuing permits to extract, levying fees, controlling forest use, and setting up nurseries. 
But it is not clear to what extent this has been successful. Oliveira's (2002) account of establishing protected areas in Bahia, Brazil describes a "horizontal decentralization" at state level that worked well-but partly since it did not pass the powers to municipal levels where the capacity to draw up plans was lacking.

Community-based natural resource management, with decentralization down to village level, has a patchy record. Reviewing cases in Asia and Southern Africa where a variety of models have been used, Shackleton, Campbell, Wollenberg, and Edmunds (2001) conclude that overall less has been achieved than expected. A significant danger in these cases was for decentralization to be highjacked by local elites, companies or government agencies. Similar problems are reported for Madhya Pradesh, India (Sundar, 2001). In this case, not only does it seem that initiatives to allow forests to be managed jointly by the forestry department and local village committees are ineffective in gaining local participation, but also that such new institutions have been imposed over local existing arrangements for forest use. For the uplands of Indonesia and the Philippines, $\mathrm{Li}$ (2002) argues that community-based management may do little to achieve ecological or social goals, partly since the interests of local forest-users are so diverse.

In the case of Ghana, Porter and Young (1998) reviewed the experience of decentralized environmental management in three Districts of coastal Ghana. The District Environment Management Committees (DEMC), set up after 1994, lacked budgets and staff and were largely ineffective, despite local concern about environmental change and depletion of local resources, and some locals having substantial environmental knowledge.

Brown (1999) reports limited success with local participation in forest management in Ghana as a whole. He stresses the very real difficulties of local communities participating effectively in forest management that arise owing to the degree of social differentiation at local level and different interests of groups with varying rights to land and trees.

Okali and Sumberg's (1999) study of irrigated farming in the community of Pamdu, Brong-Ahafo Region, records the existence of a village Land and Water Management Committee with a remit to consider bush fire control, tree planting, soil erosion control and soil fertility. But it was not clear how committed local people were to such measures. More- over, information on key processes such as the effect of cultivation close to streams and the pollution of rivers by fertilizer and pesticides was lacking.

Two key themes emerge. One is that of the importance of rights for effective participation.

\footnotetext{
"Forests, on the ground and in social theory, are now highly contested spaces, the arenas of struggles and conflicts, where both trees and forest dwellers usually find themselves on the losing side" Doornbos, Saith, and White (2000, p. 1).
}

It is not surprising that often attempts to reduce poverty run counter to the interests of the powerful who are loath to surrender their advantages, or are quick to see how changes can be used to their advantage. No wonder then that some authors (for example Brown, 1999; Li, 2002; Sundar, 2001) stress the importance of giving definite rights, and power, to locals as a precondition for effective participation. ${ }^{15}$

The other theme is that decentralization requires a sustained and skillful application of measures appropriate to the context, including the evolution of local capacity for public decision-making and implementation. Manor (1999) suggests the following necessary criteria for successful decentralization: that sufficient powers and funds be devolved; that there be administrative capacity; and that there be mechanisms to hold both elected leaders and civil servants accountable to the local public.

Given that in the case of Ghana, these conditions are met at most partially in the current state of decentralization to District level, this would suggest caution in going for a wholesale decentralization of environmental decisionmaking. But there may be some scope for some moves toward decentralization in view of the currently highly centralized decision-making. Where might a start be made? The Districts are the main focus for decentralization of government, but the District Environmental Management Committees are moribund. If they are to be brought back to life, they will need some clear function and funding.

Given, however, that environmental management has to take place locally, and that in most cases, the assent of local communities is vital for implementation of policy, it might be better to work initially at village level. The Community Forestry Committees (CFCs) reviewed hold promise as village forums and agents. But questions arise about their status and role. 
Should they be concerned with policy, or are they operational entities? Other agencies, including the Forestry Commission (FC), some nongovernmental organizations (NGOs), and the private sector can run nurseries and plant up plantations, but cannot, or should not, assume functions of local governance. This suggests that the prime role of CFCs probably lies with policy, not with operations. Should they be purely forest committees, or should they consider all natural resources? Given that households typically draw on a range of natural resources for their livelihoods, and given the ecological interactions of different resources, there is a strong case for extending the remit of the Committees to deal with all local natural resources. Widening their remit would also usefully distance the Committees from the Forestry Commission that understandably tends to see them as its agents, rather than as guardians of community interests that may at times conflict with those of the FC.

Potentially the CFCs could pass Manor's criteria. They could be given legal powers to decide on use of natural resources. They could receive funds from shares of stumpage from timber concessionaires. Administrative capacity should not be a limit if the Committee simply makes rules, rather than carries out operations. Accountability might be achieved through simple devices such as open assemblies held in the village.

Finally, if the agenda is demanding, it is worth noting Brown's (1999) assessment that Ghana has advantages at district and village level: strongly-rooted traditional leadership, respect for forest reserves, awareness of the dangers of excessive forest clearance, and the notably democratic local government that the country enjoys.

\section{NOTES}

1. From the perspective of those clearing forest, removing trees is an investment (Wunder, 2001).

2. Private investment in roads has also opened some forests, for example, mining companies and loggers constructing roads into the forest for extraction. In the case of Indonesia, in addition to the $55,000 \mathrm{~km}$ of public roads built in the outer islands for transmigration schemes, another $38,000 \mathrm{~km}$ had been opened by loggers (Sunderlin \& Resodarmo, 1999). These served to attract spontaneous settlers seeking land to farm.

3. The large Lake Volta is set aside: most of it lies outside the forest belt of southern Ghana.

4. The DAs are supervised by the Ministry of Local Government \& Rural Development (MLGRD), although that role seems largely restricted to setting the legal framework for the DAs.

5. The World Bank estimates that during the 20th century, an average of $750 \mathrm{~km}^{2}$ was deforested annually. During 1955-72, Ghana may have lost one third of its forest. Both data are from Kotey et al. (1998).

6. In southern Ghana most rural land is formally held by traditional authorities, usually chiefs, on behalf of the community as a whole. They grant usufruct rights to (clear and) cultivate to local farmers, as well as to settlers in some cases. But such rights do not commonly include the right to dispose of trees on the lands granted for farming. Standing trees remain the property of the traditional landholder. When loggers with permits seek to fell timber off the reserves, they therefore deal with the chiefs as the legal owners of the trees.

7. The analysis reports a timber industry with milling capacity at $5.1 \mathrm{Mm}^{3}$ a year and a total harvest of $3.72 \mathrm{M} \mathrm{m}^{3}$ a year, as compared to a annual allowable cut of just $1 \mathrm{Mm}^{3}$ a year.

8. On other hand some question the depth to which some norms are held locally. For example, Okali and Sumberg (1999) argue that "...interest in controlling land use adjacent to watercourses is being driven in large part by a kind of meta-narrative about environmental change and degradation, which has few apparent empirical links to actual situations in rural Ghana" (p. 100). They also wonder to what extent there is true commitment to some of the environmental problems stated by locals and locally-based government staff, since public expression of environmental concerns were instrumental in obtaining funds from government and aid-donor funded programs.

9. A District by-law has to be gazetted nationally to have legal standing. To gain this the DA should send drafts of by-laws to the Ministry of Local Government for transmission to the Office of the Attorney General for legal scrutiny prior to gazetting. It seems that in practice only an (unknown) fraction of district by-laws go through this somewhat cumbersome process. Consequently, there are by-laws that, not having been 
gazetted, could be challenged in the courts. There appears to be no central registry of the by-laws passed by the 110 districts of Ghana.

10. Amanor, Brown, and Richards (2002), on the basis of studies in the north of Brong-Ahafo Region, arrive at similar (and perhaps stronger) judgments. At local level, they argue, environmental policy is all too often implemented blindly, or ignored, or used to further narrow interests. Environmental policies have low priority and are poorly implemented. Furthermore, some of them lack empirical bases, create a culture of blame and are open to manipulation.

11. The four communities differed in size. Aboabo had as many as 300 households, Tanoso had even more so that the census only covered a portion of the village (106 households); in comparison Adiembra and Botenso were hamlets with just 59 and 68 households, respectively.

12. Given that crop farmers typically hire in labor at peak periods, from where does this labor come? The

\section{REFERENCES}

Amanor, K. S. (1999). Global restructuring and land rights in Ghana. Forest food chains, timber and rural livelihoods. Research Report No. 108. Uppsala, Sweden: Nordiska Afrikainstitutet.

Amanor, K., Brown, D. \& Richards, M. (2002). Poverty dimensions of public governance and forest management in Ghana. Final Technical Report, NRSP Project R7957, June 2002. London: Overseas Development Institute \& Legon, Ghana: Institute of African Studies, University of Ghana.

Angelsen, A., \& Kaimowitz, D. (1999). Rethinking the causes of deforestation: Lessons from economic models. World Bank Research Observer, 14(1), 73-98.

Barbier, E. (1991). Tropical deforestation. In D. W. Pearce et al. (Eds.), Blueprint II: Greening the world economy. London: Earthscan.

Bardhan, P. (1996). Decentralised development. Indian Economic Review, 31(2), 139-156.

Bass, S., Mayers, J., Ahmed, J., Filer, C., Khare, A., Kotey, N. A., Nhira, C., \& Watson, V. (1997). Policies affecting forests and people: Ten elements that work. Commonwealth Forestry Review, 76(3), 186-190, 226, 228.

Binswanger, H. P. (1991). Brazilian policies that encourage deforestation in the Amazon. World Development, 19(7), 821-829.

Brown, D. (1999). Principles and practice of forest comanagement: Evidence from West-Central Africa. European Union Tropical Forestry Paper No. 2. London: Overseas Development Institute \& Brussels: European Commission.

Brown, K. (2001). Cut and run? Evolving institutions for global forest governance. Journal of International Development, 13, 893-905. answer may well be that much of the hired labor used on fields in these villages is provided by seasonal migrants from northern Ghana.

13. The mean was much higher at 152 days, reflecting a highly-skewed and widely-spread distribution of days worked.

14. Assessing perceptions is particularly difficult when significant stakeholders are marginalized from public debates, since they live in remote areas, are illiterate and otherwise lack the organization and skills to participate effectively. In general, public debate on environmental change and its consequences in Ghana is muted.

15. Okali and Sumberg (1999) suggest that a "livelihoods precautionary principle" should be adopted when environmental policies are considered: that is, that existing rural livelihoods should not be put at risk if there is doubt over the need for policy. Here the rights apply to the activity rather than to the resources.

Doornbos, M., Saith, A., \& White, B. (2000). Forest lives and struggles: An introduction. Development and Change, 31(1), 1-10.

Forestry Commission (2001a). Ghana wood industry and log export ban study. (Final Report, May 2001). Accra, Ghana: Forestry Commission.

Forestry Commission (2001b). Desktop Review of Social Responsibility Agreements. Internal Review Memo, July 2001. Accra, Ghana: Forestry Commission.

Kotey, N. A., Francois, J., Owusu, J. G. K., Yeboah, R., Amanor, K. S. \& Antwi, L. (1998). Falling into place, Ghana Country Study, Policy that works for forest and people series no. 4. London: International Institute for Environment \& Development.

Larson, A. M. (2002). Natural resources and decentralization in Nicaragua: Are local governments up to the job? World Development, 30(1), 17-31.

Li, T. M. (2002). Engaging simplifications: Communitybased resource management, market processes and state agendas in upland Southeast Asia. World Development, 30(2), 265-283.

Manor, J. (1999). The political economy of democratic decentralization. Washington, DC: The World Bank.

Mather, A. S., \& Chapman, K. (1995). Environmental resources. Harlow, UK: Longman Scientific \& Technical.

Okali, C. \& Sumberg, J. (1999). Policy implications of enterprise agriculture as a component of rural livelihood diversification in West Africa. Final Report, ESCOR Grant R6780.

de Oliveira, J. A. P. (2002). Implementing environmental policies in developing countries through decentralization: The case of protected areas in Bahia, Brazil. World Development, 30(10), 1713-1736.

Poffenburger, M. (Ed.). (1996). Communities and forest management. A report of the IUCN Working Group 
on Community Involvement in Forest Management, with recommendations to the Intergovernmental Panel on Forests. Washington, DC: IUCN-The World Conservation Union.

Porter, G., \& Young, E. (1998). Decentralized environmental management and popular participation in coastal Ghana. Journal of International Development, 10, 515-526.

Salagrama, V. (2000). India literature review, Draft for Sustainable Coastal Livelihoods Project. Gandhi Nagar, Kakinada, Andhra Pradesh, India: ICM. March 2000. Mimeo.

Sandford, S. (1983). Management of pastoral development in the Third World. Chichester, UK: John Wiley.

Shackleton, S., Campbell, B., Wollenberg, E. \& Edmunds, D. (2001). Devolution and community-based natural resource management: Creating space for local people to participate and benefit? Natural Resources Perspectives Paper Number 76, March 2002. London: Overseas Development Institute.

Sundar, N. (2001). Is devolution democratization? World Development, 29(12), 2007-2023.

Sunderlin, W., \& Resodarmo, I. A. P. (1999). The effect of population and migration on forest cover in Indonesia. Journal of Environment and Development, $8(2), 152-169$.

Templeton, S. R., \& Scherr, S. J. (1999). Effects of demographic and related microeconomic change on land quality in hills and mountains of developing countries. World Development, 27(6), 903918.

Wunder, S. (2001). Poverty alleviation and tropical forests - what scope for synergies? World Development, 29(11), 1817-1833. 